\title{
Towards a sociolinguistic analysis of the current relevance of androcentric proverbs in Peninsular Spanish
}

\author{
Benedicta Adokarley Lomotey \\ Lecturer \\ Department of Modern Languages \\ University of Ghana, Legon, Ghana \\ Email: balomotey@ug.edu.gh
}

Submitted: May 2, 2018 / Accepted: February 18, 2019 / Published: October 4, 2019

\begin{abstract}
Gender-related Spanish proverbs are often reflections of what Swim, Aikin, Hall and Hunter (1995) identify as Old-Fashioned Sexism which make these proverbs appear outdated. Using questionnaires designed based on both the Modern Sexism and Old-Fashioned Sexism theories of Swim et al (1995), the author investigates the current relevance of some genderrelated proverbs. The study reveals that overtly sexist proverbs are uncommon in modern times. However, androcentricism and sexism are still evident in some contemporary Spanish proverbs because some old-fashioned overtly sexist proverbs have refashioned themselves into proverbs that appear covertly benevolent to women, concealing the 'traditional' and bluntly sexist ones.
\end{abstract}

Keywords: proverbs, feminist linguistics, modern sexism scale, old-fashioned sexism scale, linguistic androcentricism

\section{Introduction}

The origin of paremiology is often traced back to the $16^{\text {th }}$ century with the publication of Erasmus of Rotterdam's collection of proverbs in 1515 . Recently, proverbs have occupied a central focus in sociolinguistic research due to their popularity, and their traditional and pragmatic values. They are universal in nature as they can be found in all societies around the world. Interestingly, despite the diversity in languages and cultures, certain phenomena, which appear to be inherent in humans irrespective of social 
and cultural differences, can be identified from a cross-cultural analysis of some proverbs. One such aspect of social values and ideologies, which is constantly found in many proverbs, are issues concerning gender relations.

The Spanish language in particular, provides an immense source for analysis of proverbs in general and many of them reflect gender power relations. Indeed, Calero Fernández (1999, p. 132) investigates 10,884 proverbs and identifies 85 foibles of women and only 17 innate qualities. On his part, Tirado Zarco (1987) also categorises $5.56 \%$ positive proverbs, $10 \%$ neutral ones and $76.79 \%$ negative ones about women.

Members of a given linguistic community often identify proverbs in their language as part of their linguistic heritage. Proverbial sayings are therefore passed on from generation to generation. Although this is generally done orally through natural speech with parents, other relatives and friends, speakers also learn them through Internet usage, the media and in educational institutions. Also, Taylor notes that people "buy and read collections of proverbs to awaken and enlarge reflections on the world and the nature of man, to suggest subjects for conversation, or to provide themselves with comment [sic] appropriate to situations in daily life" (Taylor, 1996, p. 45). Subsequently, proverbs are excellent vehicles for the transmission of a society's values, good and bad.

As works by Calero Fernández (1999), Martínez Garrido (2001), and Bosch, Victòria and Alzamora (2006) show, a significant amount of research on Spanish proverbs exist. However, not much attention has been given to their current relevance. Subsequently, given the adverse effects of hierarchical gender relations on a society's progress and development ${ }^{1}$, this paper sought to investigate the current relevance or otherwise of gender related Spanish proverbs, which promote male dominance and female subordination. In the next section, we will explain the method used including the materials and procedure, analytical framework, and participants. The findings will then be discussed in the following section and a conclusion will be made in the final section.

\section{Method}

It was necessary to employ a multifaceted approach in the collection and the analyses of data because of the multidimensional nature (social,

${ }^{1}$ The United Nations Organization at the IV World Conference in 1995 recognized that violence against women is an obstacle to achieving the objectives of equality, development and peace and violates and undermines the enjoyment of human rights and fundamental freedoms (BOE, 2004). 
Lomotey, B.A./Towards a sociolinguistic analysis of the current relevance of androcentric proverbs in Peninsular Spanish

psychological and linguistic) of the problem under study. With insight from feminist linguistic theory and the Modern and Old-Fashioned Sexism theories (Swim, Aikin, Hall, \& Hunter, 1995), the study analysed the gender ideologies inherent in Spanish proverbs. Through the lenses of Lakoff and Johnson's (1980) theory of metaphor, it also examined how these gender ideologies enact and reinforce gender bias and violence. Finally, the author examined participants' familiarity with the proverbs under study through the administration of questionnaires.

\section{Materials and procedure}

In the analysis of the gender ideologies inherent in Spanish proverbs, sample proverbs were culled from existing literature by authors such as Calero Fernández (1999), Martínez Garrido (2001), Bosch, Victòria, and Alzamora (2006), Mestre Chust (2007), DonAabangens (2010), and Fernández Poncela (2012). Due to the substantial numbers of gender related proverbs, these proverb examples were carefully selected and categorised within the framework of the Old-Fashioned Sexism Scale (Swim et al., 1995) with the aim of obtaining illustrations of the different ideologies inherent in the wide variety of proverbs. The categorisation was done by taking into account proverbs which reflect ideologies of old-fashioned sexism; i.e. stereotypical conceptions of gender and open discrimination.

In order to determine their currency or obsolescence, Internet searches were carried out on the selected proverbs on online corpora. While it was complex and difficult to find these proverbs in the corpora used, certain varieties such as the following were successfully identified on the website of the Centro Virtual de Cervantes (Instituto Cervantes, 2000) and the Corpus del Español (Davies, 2002).

- Mujer en casa y con la pata quebrada [the woman in the house and with a broken leg]. ${ }^{2}$

- La Mujer y el vino sacan al hombre de tino [women and wine prevent men from reasoning].

- La Mujer y el vino hacen del hombre un pollino [women and wine turn men into idiots].

An annotation indicated the second proverb advises one to 'avoid excesses of drinking and lust' and it was described as 'hardly used'. The third one was explained as 'teaches that these three things, if one submits himself to them with passion, are causes of dangerous results' (Instituto Cervantes, 2000).

${ }^{2}$ Meaning women should be kept at home [broken feet] 
The author was further interested in investigating the rate of usage through questionnaires that contained both closed-ended and open-ended questions. While the former provided quantitative data, the latter offered qualitative information that gave further insights on gender ideologies in peninsular Spanish ${ }^{3}$ proverbs.

\section{Analytical framework}

Swim et al. (1995) developed the Modern Sexism Scale (henceforth MSS) to measure covert prejudice against women and the Old-Fashioned Sexism Scale (henceforth OFSS) to measure traditional sexist beliefs about women. The latter (Old-Fashioned Sexism) is characterized by endorsement of traditional gender roles, differential treatment of women and men, and stereotypes about lesser female competence. As works by Martínez Garrido (2001) and Fernández Poncela (2010) show, these attitudes and beliefs which are examples of overt sexism play a significant role in gender discrimination and gender violence.

While both types of sexism are built on prejudicial beliefs that promote discriminatory behaviour, they are differentiated by the fact that Modern Sexism is covert; probably due to current social awareness and criticism of gender discrimination. Modern sexists would thus tend to deny gender discrimination and show antagonism towards women's demands (see Swim et al., 1995). On the other hand, Old-Fashioned Sexism is an overt type of sexism that explicitly endorses negative attitudes towards women.

For the present purpose of analysing androcentrism ${ }^{4}$ in Spanish proverbs and its influence on the thoughts and behaviour of speakers, the Modern Sexism theory was relevant for the design of the questionnaire; specifically, in the formulation of open ended questions. Additionally, the Old-Fashioned Sexism theory was an appropriate analytical framework for the categorisation of proverbs because the ideologies endorsed by these discourses are mostly reproductions of traditional and conservative beliefs about women and men.

\section{Participants}

Convenience sampling was used in the selection of participants. This sampling procedure was used because the study is an exploratory research that aims at obtaining a gross preliminary estimation of the truth. Nonetheless, one basic criterion was applied. Native Spaniards or individuals

${ }^{3}$ The standard form of Spanish spoken in the Iberian Peninsula.

${ }^{4}$ The dominance of masculine interests or a masculine point of view. 
Lomotey, B.A./Towards a sociolinguistic analysis of the current relevance of androcentric proverbs in Peninsular Spanish who had a good knowledge of the Spanish language were interviewed. Additionally, non-Spaniards who had lived in Spain for several consecutive years (up to 10 years) were included in the study. These participants were considered appropriate for the collection of data utilized for the study as they were individuals who had reasonable awareness of their sociocultural and linguistic environment. In all, 124 participants were interviewed. The following table presents their demographic information.

Table 1: Demographic profile of sample respondents

\begin{tabular}{|c|c|c|c|}
\hline $\begin{array}{l}\text { DEMOGRAPHIC } \\
\text { PROFILE }\end{array}$ & VARIABLE & NUMBER & PERCENTAGE \\
\hline \multirow[t]{3}{*}{ Sex } & Male & 28 & $22.6 \%$ \\
\hline & Female & 95 & $76.6 \%$ \\
\hline & Unspecified & 1 & $0.8 \%$ \\
\hline \multirow[t]{6}{*}{ Age } & $18-30$ & 50 & $40.3 \%$ \\
\hline & $31-40$ & 37 & $29.8 \%$ \\
\hline & $41-50$ & 13 & $10.5 \%$ \\
\hline & $51-60$ & 15 & $12.1 \%$ \\
\hline & $61-70$ & 8 & $6.5 \%$ \\
\hline & $70+$ & 1 & $0.8 \%$ \\
\hline \multirow[t]{7}{*}{ Nationality } & Spanish & 72 & $58.1 \%$ \\
\hline & South American & 25 & $20.2 \%$ \\
\hline & North American & 7 & $5.6 \%$ \\
\hline & African & 13 & $10.5 \%$ \\
\hline & $\begin{array}{l}\text { Other European coun- } \\
\text { tries }\end{array}$ & 4 & $3.2 \%$ \\
\hline & Asia & 1 & $0.8 \%$ \\
\hline & Unspecified & 2 & $1.6 \%$ \\
\hline \multirow[t]{5}{*}{ Level of education } & None & o & o\% \\
\hline & Primary Education & 3 & $2.4 \%$ \\
\hline & Secondary Education & 15 & $12.1 \%$ \\
\hline & University Education & 95 & $76.6 \%$ \\
\hline & Professional Training & 10 & $8.1 \%$ \\
\hline
\end{tabular}




\section{Findings}

In order to explore the relevance of androcentric proverbs in modern times thirteen sample proverbs were selected. Before reviewing the results of the study it is worth emphasizing that the data are, strictly speaking, only valid for the chosen group of proverb samples analysed.

As mentioned above, each proverb represented an ideology. Participants were then asked to indicate their level of familiarity with the proverbs by choosing either a) 'conocido' if the proverb was familiar, b) 'desconocido' if it was not familiar or c) 'no lo conozco, sin embargo, creo que transmite una percepción corriente' if the respondent thought the perception inherent in the proverb was familiar. Participants were informed that they could only choose one answer to each question. The thirteen proverbs selected and participants' responses are presented in table 2.

Table 2: Modern relevance of sample misogynous proverbs

\begin{tabular}{|l|l|l|l|}
\hline Proverb & Known & Unknown & $\begin{array}{l}\text { I do not } \\
\text { know it, } \\
\text { however, } \\
\text { I think it } \\
\text { transmits } \\
\text { a current } \\
\text { perception. }\end{array}$ \\
\hline $\begin{array}{l}\text { 1. La mujer en casa y con la pata quebra- } \\
\text { da [The woman in the house and with a } \\
\text { broken leg]. }\end{array}$ & $35.5 \%$ & $45.2 \%$ & $19.4 \%$ \\
\hline $\begin{array}{l}\text { 2. Los hombres machos no hablan, pelean } \\
\text { [Real men don't talk. They fight]. }\end{array}$ & $25.8 \%$ & $44.4 \%$ & $29.8 \%$ \\
\hline $\begin{array}{l}\text { 3. La mujer y el vino sacan al hombre de } \\
\text { tino [Women and wine prevent men from } \\
\text { reasoning]. }\end{array}$ & $28.2 \%$ & $46 \%$ & $25.8 \%$ \\
\hline $\begin{array}{l}\text { 4. El hombre debe ganarlo y la mujer } \\
\text { administrarlo [Men are the breadwinners } \\
\text { and women are the homemakers]. }\end{array}$ & $34.7 \%$ & $36.3 \%$ & $29 \%$ \\
\hline $\begin{array}{l}\text { 5. El que tiene mujer bella, le pone tranca } \\
\text { a la puerta [He who has a beautiful wife } \\
\text { must lock his door with a crossbar]. }\end{array}$ & $21.1 \%$ & $47.2 \%$ & $31.7 \%$ \\
\hline $\begin{array}{l}\text { 6. La mujer habladora, duelo tiene donde } \\
\text { mora [Talkative women provoke fights } \\
\text { wherever they go]. }\end{array}$ & $9.7 \%$ & $62.9 \%$ & $27.4 \%$ \\
\hline
\end{tabular}


Lomotey, B.A./Towards a sociolinguistic analysis of the current relevance of androcentric proverbs in Peninsular Spanish

\begin{tabular}{|l|l|l|l|}
\hline $\begin{array}{l}\text { 7. A un hombre rico no le repares si es feo o } \\
\text { bonito [So long as man is rich, it doesn't } \\
\text { matter whether he is handsome or ugly]. }\end{array}$ & $25.8 \%$ & $39.5 \%$ & $34.7 \%$ \\
\hline $\begin{array}{l}\text { 8. A la mujer brava, soga larga [The } \\
\text { hot-headed woman deserves to be } \\
\text { hanged]. }\end{array}$ & $12.9 \%$ & $62.1 \%$ & $25 \%$ \\
\hline $\begin{array}{l}\text { 9. El amor entra por la cocina [Love enters } \\
\text { through the kitchen]. }\end{array}$ & $59.7 \%$ & $19.4 \%$ & $21 \%$ \\
\hline $\begin{array}{l}\text { 10. La mujer y el vidrio siempre están en } \\
\text { peligro [Women and glass are always in } \\
\text { danger]'. }\end{array}$ & $12.1 \%$ & $58.9 \%$ & $29 \%$ \\
\hline $\begin{array}{l}\text { 11. Matrimonio de buena fortuna: siete var- } \\
\text { ones y de hembras sólo una [A marriage } \\
\text { that brings a good fortune has seven sons } \\
\text { and only one daughter]. }\end{array}$ & $7.3 \%$ & $70.2 \%$ & $22.6 \%$ \\
\hline $\begin{array}{l}\text { 12. El hombre se casa cuando quiere y la } \\
\text { mujer cuando puede [Men marry when } \\
\text { they want but women marry when they } \\
\text { can]. }\end{array}$ & $30.1 \%$ & $42.3 \%$ & $27.6 \%$ \\
\hline $\begin{array}{l}\text { 13. Al asno y a la mujer, a palos se han de } \\
\text { vencer [Women and donkeys need to be } \\
\text { conquered with lashes]. }\end{array}$ & $20.3 \%$ & $54.5 \%$ & $25.2 \%$ \\
\hline
\end{tabular}

As can be observed from the table, participants generally showed little familiarity with the misogynous proverbs analyzed. The sample proverbs above are reflections of perceptions of women as evil/ untrustworthy (3, 6), animals (13), objects/ possessions (5), and lesser human beings $(8,11)$. These ideologies are echoes of Old-Fashioned Sexism which is characterized by endorsement of traditional gender roles, differential treatment of women and men, and stereotypes about lesser female competence. These overtly androcentric, hostile and sexist proverbs scored relatively low marks as the majority of participants indicated they were not familiar with them.

However, interestingly, the 'women as homemakers' category was the only category that scored a clearly high mark. While the majority of participants $(59.7 \%)$ said they were familiar with proverb 9 which falls within this category, quite a number (21\%) said it was a common stereotype, and a relatively low amount (19.4 \%) said they were not familiar with it. It must be noted that while the analogy between women and animals, objects and evil are examples of overt sexism, the 'women as homemakers' category (e.g. proverbs 1, 4, and 9) is an example of covert or benevolent sexism. ${ }^{5}$

${ }^{5}$ Glick \& Fiske (1996) identify hostile Sexism and benevolent Sexism as two different but interrelated components of 
Consequently, it appeared that due to modernization and public censure of gender discrimination, misogyny and gender violence, speakers are more likely to demonstrate covert sexism while overt sexism is frowned upon.This is evidenced in the organic law $1 / 2004$ of $28^{\text {th }}$ December, for 'Comprehensive Protection Measures against Gender Violence' - which clearly states that gender violence "is no longer an 'invisible crime', but produces a collective rejection and an obvious social alarm" (BOE, 2004, p. 42166).

The majority of participants were of the opinion that the perceptions demonstrated in these proverbs are outdated and are exaggerations since they do not reflect present Spanish sociocultural ideology. In conflict with this affirmation, however, the majority opined that gender stereotypes are still rampant in Spain and gender imbalance still exists against women. Of particular importance for this study was the affirmation by a participant (extract 6) that women still suffer gender discrimination and consequently, it is necessary to promote gender equality between women and men. As authors such as Philips (2003) and Fernández Poncela (2010) show, this can be done by identifying linguistic androcentrism and misogynous ideologies in language with the aim of creating an awareness and promoting the use of gender fair language. The results on participants' opinions about social gender discrimination are summarized in table 3 below:

Table 3: Results for questions on social gender discrimination

\begin{tabular}{|l|l|l|}
\hline PREGUNTA [QUESTION] & OPCIONES [OPTIONS] & $\begin{array}{l}\text { RESPUESTAS } \\
\text { [ANSWERS] }\end{array}$ \\
\hline $\begin{array}{l}\text { Muchos de los valores que trans- } \\
\text { miten estos refranes siguen } \\
\text { [Many of the values transmitted by } \\
\text { these proverbs are: }\end{array}$ & Vigentes[current] & $39.2 \%$ \\
\cline { 2 - 3 } $\begin{array}{l}\text { Muchos de estos refranes son: } \\
\text { [Many of these proverbs are: }\end{array}$ & $\begin{array}{l}\text { Exageraciones ya que reflejan } \\
\text { el contrario de la ideología } \\
\text { sociocultural [exaggerations } \\
\text { because they do not reflect } \\
\text { Spanish sociocultural ideologies] }\end{array}$ & $45.8 \%$ \\
\cline { 2 - 3 } & $\begin{array}{l}\text { Precisos, ya que reflejan la } \\
\text { manera de pensar de los miem- } \\
\text { bros de la sociedad [precise, be- } \\
\text { cause they reflect the worldview } \\
\text { of speakers] }\end{array}$ & $37.5 \%$ \\
\cline { 2 - 3 } & \begin{tabular}{l} 
No lo sé [I do not know] \\
\hline
\end{tabular} & $16.7 \%$ \\
\hline
\end{tabular}

their Ambivalent Sexism Theory. The first (hostile sexism), refers to negative attitudes and intolerance towards women. The authors define the second (benevolent sexism) as 'a set of interrelated attitudes toward women that are sexist in terms of viewing women stereotypically and in restricted roles but that are subjectively positive in feeling tone (for the perceiver)' (Glick \& Fiske, 1996, p. 491). 
Lomotey, B.A./Towards a sociolinguistic analysis of the current relevance of androcentric proverbs in Peninsular Spanish

\begin{tabular}{|c|c|c|}
\hline \multirow{3}{*}{$\begin{array}{l}\text { ¿Sigue habiendo ideas falsas o } \\
\text { prejuicios hacia el varón o hacia } \\
\text { la mujer? [Does society still have } \\
\text { false ideas or prejudice against } \\
\text { men or women?] }\end{array}$} & Sí [yes] & $91.7 \%$ \\
\hline & $\mathrm{No}[\mathrm{no}]$ & $0 \%$ \\
\hline & No lo sé [I do not know] & $8.3 \%$ \\
\hline \multirow{2}{*}{$\begin{array}{l}\text { ¿En caso afirmativo cuál de los } \\
\text { sexos sufre más estos prejuicios? } \\
\text { [If yes, which of the sexes suffers } \\
\text { more discrimination?] }\end{array}$} & Varón [men] & $3 \cdot 3 \%$ \\
\hline & Mujer [women] & $96.7 \%$ \\
\hline \multirow{3}{*}{$\begin{array}{l}\text { ¿Siguen existiendo actividades } \\
\text { propias de cada sexo? [Does } \\
\text { society still have expectations of } \\
\text { traditional gender roles?] }\end{array}$} & Sí [yes] & $78.3 \%$ \\
\hline & No $[\mathrm{no}]$ & $13 \cdot 3 \%$ \\
\hline & No lo sé [I do not know] & $8.3 \%$ \\
\hline \multirow{4}{*}{$\begin{array}{l}\text { La mujer sigue recibiendo } \\
\text { actualmente un trato desigual. } \\
\text { En consecuencia, es necesario } \\
\text { educar en nuevos valores de } \\
\text { igualdad y corresponsabilidad } \\
\text { en las relaciones entre varones y } \\
\text { mujeres. [Discrimination against } \\
\text { women still exists. Consequently, } \\
\text { it is necessary to educate society } \\
\text { about equality and joint responsi- } \\
\text { bility between women and men] }\end{array}$} & Estoy de acuerdo [I agree] & $47.4 \%$ \\
\hline & $\begin{array}{l}\text { Estoy completamente de acuer- } \\
\text { do [I completely agree] }\end{array}$ & $49.1 \%$ \\
\hline & No estoy de acuerdo [I disagree] & $3.4 \%$ \\
\hline & $\begin{array}{l}\text { Estoy completamente en desac- } \\
\text { uerdo [I completely disagree] }\end{array}$ & O\% \\
\hline
\end{tabular}

The inclusion of an open comment section also provided the possibility for a qualitative analysis. Some participants believed such ideologies are rampant especially in the rural areas and that presently, gender discrimination has been mitigated:

\section{Extract 1}

Es importante remarcar que estos valores están sobre todo presentes en las sociedades rurales y más afianzados en los miembros de primeras generaciones (6o para adelante) [It's important to note that these values are rampant especially in rural societies and amongst the earlier generations (6o onwards)]. (Male, 18-30, Spaniard, Spanish as a Foreign Language Lecturer)

\section{Extract 2}

La sociedad Española está cambiando, las personas jóvenes han recibido mucha más educación que sus progenitores y son menos machistas, intentan llevar a su vida y su profesión la igualdad de derechos entre mujeres $y$ hombres [the Spanish society is changing, the youth have received more education than their elders and are less chauvinist, they try to be gender fair both in their professional and personal affairs]. (Female, 61-70, Spaniard, Geology Lecturer)

However, the data on gender violence ${ }^{6}$ in Spain appears to challenge the

${ }^{6}$ The organic law $1 / 2004$ of $28^{\text {th }}$ December, defines gender violence as "a violence that is directed at women (my emphasis) for the very fact of being women, because they are considered, by their aggressors, as lacking the minimum 
Lomotey, B.A./Legon Journal of the Humanities Vol. 30.1 (2019)

argument that such androcentric perceptions are more rampant in the rural areas and among the aged. These negative descriptions of women which appear in proverbs are very much related to a social reality which cannot be overlooked, i.e. societal gender discrimination and gender violence. An examination of the statistics on deaths resulting from gender violence in Spain on the Statistics Portal of the Institute for Women and for Equal Opportunities of the government of Spain, confirms the misogynous substratum of systemic prejudices reflected in these linguistic realities.

Table 4: Statistics on deaths resulting from gender violence in Spain (According to Autonomous Community)

\begin{tabular}{|c|c|c|c|c|c|c|}
\hline AUTONOMOUS REGIONS & 2019 & 2018 & 2017 & 2016 & 2015 & TOTAL \\
\hline ANDALUCÍA & 2 & 12 & 7 & 5 & 14 & 40 \\
\hline ARAGÓN & 1 & 3 & o & 3 & 1 & 8 \\
\hline ASTURIAS & $\mathrm{o}$ & 3 & o & 2 & 3 & 8 \\
\hline BALEARES & $\mathrm{O}$ & 1 & o & 6 & 1 & 8 \\
\hline CANARIAS & 1 & 2 & 4 & 3 & 3 & 13 \\
\hline CANTABRIA & 1 & o & o & o & 1 & 2 \\
\hline CASTILLA Y LEÓN & 1 & 2 & o & 6 & 2 & 11 \\
\hline CASTILLA - LA MANCHA & $\mathrm{O}$ & 2 & 6 & 2 & 1 & 11 \\
\hline CATALUÑA & 1 & 7 & 8 & 6 & 6 & 28 \\
\hline C. VALENCIANA & o & 2 & 8 & 6 & 11 & 27 \\
\hline EXTREMADURA & o & o & 2 & 1 & 1 & 4 \\
\hline GALICIA & o & 3 & 2 & 4 & 8 & 17 \\
\hline MADRID & 1 & 5 & 8 & 3 & 4 & 21 \\
\hline MURCIA & $\mathrm{O}$ & 1 & 3 & o & 1 & 5 \\
\hline NAVARRA & $\mathrm{O}$ & 2 & 1 & o & 0 & 3 \\
\hline PAÍS VASCO & $\mathrm{O}$ & 2 & 2 & 1 & 3 & 8 \\
\hline LA RIOJA & $\mathrm{O}$ & $\mathrm{O}$ & $\mathrm{O}$ & o & $\mathrm{O}$ & $\mathrm{O}$ \\
\hline CEUTA & o & o & o & o & o & o \\
\hline MELILLA & $\mathrm{O}$ & o & o & 1 & $\mathrm{O}$ & 1 \\
\hline
\end{tabular}

Source: (Instituto de la Mujer y para la Igualdad de Oportunidades, 2019)

As observed in the above table, contrary to participants assertion that gender violence is more rampant in rural areas, Madrid, the capital city of Spain, had the fourth highest case of gender violence out of the total of 17 rights of freedom, respect and decision-making capacity" (BOE, 2004). 
Lomotey, B.A./Towards a sociolinguistic analysis of the current relevance of androcentric proverbs in Peninsular Spanish

autonomous regions and two autonomous cities (Ceuta and Melilla) for the years 2015 to 2019. Although one might argue that these are social facts and not linguistic, it must be noted that the proverbs analysed function as a discursive strategy that sustains the power of the dominant group over the dominated group and by so doing, they reinforce gender stereotypes and ideologies and help to propagate gender discrimination and violence. As Crida Alvarez (2001, p. 109) notes, gender related proverbs in Spanish ${ }^{7}$ can be classified psycho-socially, and this classification demonstrates the sexist behaviours in the Spanish society.

The following observations made by some participants confirm that although androcentrism appears to have been mitigated in Spain, more work is still needed to attain true gender equality. Indeed, in the words of one participant "society has changed and improved a lot. But there is still a lot to be done" (Male, 18-30, Spaniard, Banker)

Extract 3

El hecho de que sigan vigentes refranes y frases basados en la discriminación hacia la mujer es señal de que aún queda mucho por hacer a nivel social: cambiar la mente de las personas es lo más difícil [The fact that there are still proverbs and phrases based on discrimination against women is a sign that there is still much to be done at a social level: changing the minds of people is the most difficult thing]. (Female, 41-50, Spaniard, Philologist)

\section{Extract 4}

Parte del problema es la religión (cualquiera) que eleva al hombre y subyuga a la mujer. Esto no ha cambiado. Cuando la mujer viola ciertas normas culturales como tener varios amantes, la sociedad en general continúa llamándola 'prostituta,' 'mujerzuela,' 'ninfomaníaca,' etc. No conozco ningún tal adjetivo para el hombre que tenga la fuerza de los insultos hacia las mujeres. El tildar a un hombre de 'mujeriego' no tiene el mismo impacto lingüístico o sociocultural [Part of the problema is religion (anyone) that elevates men and subjugates women. This has not changed. When a woman violates certain cultural norms such as having several lovers, society in general continues to call her a "prostitute," "whore," "nymphomaniac," etc. I do not know any such adjective for men which is as offensive as the insults used against women. Tagging a man as a 'womanizer' does not have the same linguistic or sociocultural impact]. (Female, 61- 70, American, University lecturer)

It is necessary to evaluate this apparent conflict between linguistic features and social facts. That is, the contrast in low scores for misogynous

\footnotetext{
${ }^{7}$ As well as Greek, which he analyses in the same study.
} 
proverbs and gender related crime rates in Spain. The disconnect between the number of participants that opined that the sample proverbs are outmoded and exaggerations on the one hand, and on the other hand the high number of participants who affirmed the existence of gender inequality against women, might be explained by three factors.

Firstly, the responses obtained for the first part of the questionnaire (proverb frequency) and the second part (the existence of gender discrimination), could be an indication of modern sexism which is characterised by a denial of discrimination against women. In addition, it must be noted that some participants (11.6 \%) chose 'I don't remember' for how they acquired these proverbs. It is possible that these participants unconsciously (naturally) acquired these proverbs in their sociocultural and linguistic environment as against in educational institutions, for example, where they could have been learnt in gender and language lectures in which such proverbs are analyzed and criticized to create an awareness. This could be a confirmation that the proverbs studied are still present and used by some speakers. Indeed, an interestingly high number of participants (64.3 \%) also indicated they acquired the familiar proverbs from their parents. Subsequently, this confirms that these discourses are still being passed on from generation to generation.

Figure 1: Modes of acquisition of sample proverbs

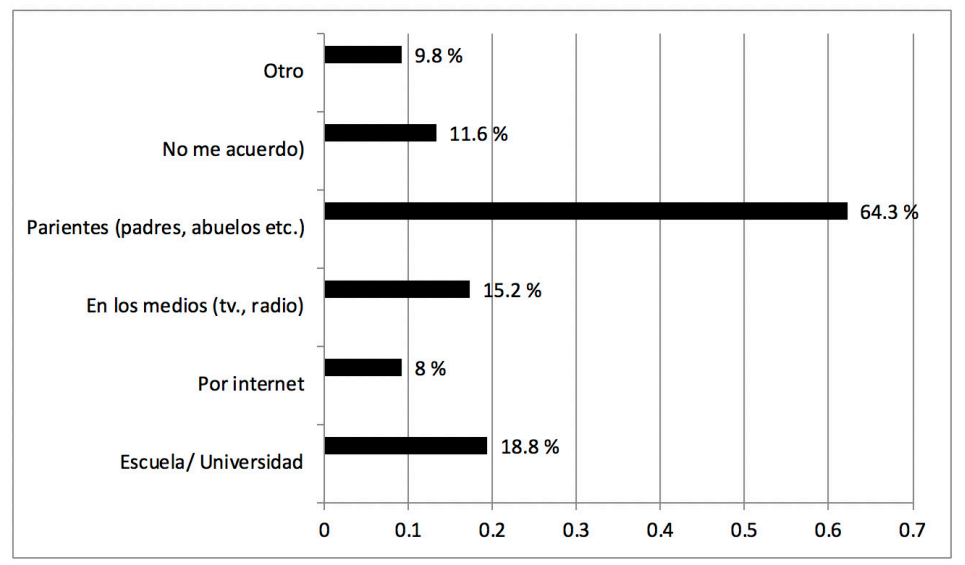

Otro 'other'; No me acuerdo 'I do not remember'; Parientes (padres, abuelos etc.) 'relatives (parents, grandparents etc.)'; En los medios (tv, radio) 'in the media (tv, radio)'; Por internet 'through the internet'; Escuela/ Universidad 'School/ University'.

Secondly, the idea behind including option $\mathrm{C}$ as an alternative to 
Lomotey, B.A./Towards a sociolinguistic analysis of the current relevance of androcentric proverbs in Peninsular Spanish

'conocido' and 'desconocido' was to explore whether the ideology inherent in each proverb was still rampant or relevant in present times. The selection of option 'c' for any given proverb could also indicate that proverb was unknown but there was a possibility of the respondent knowing other variants of the proverb in question. Consequently, the number of participants who selected option $\mathrm{C}$ could also be an indication of the persistence of misogynous ideologies; whether they are purely sociocultural or linguistic. The following responses by some participants confirm that other variations of these proverbs might be more familiar for some respondents:

\section{Extract 5}

Me da la impresión de que dichos refranes, al menos de la forma en que están escritos, son usados más comúnmente en Sudamérica. Existen algunos parecidos en España, pero no son expresados de la misma forma ni hay tantos como los enlistados aquí [I have the impression that these proverbs, at least in the form in which they are written, are used more in South America. Similar ones exist in Spain, but they are not expressed in the same way neither are there as many as those listed here]. (Female, 1830, Spaniard, Researcher)

\section{Extract 6}

Nuestros refranes reflejan las actitudes sexistas de la cultura. Es hora de cambiarlos y adoptar nuevas ideas que no solo dejan participar a la mujer en lo que antes se consideraban actividades o espacios solo para hombres, sino, y a mi criterio aún más importante, debemos valorar más el trabajo que la mujer siempre ha hecho para construir comunidades, familias, etc. [Our proverbs reflect sexist cultural attitudes. It's time to change them and adopt new ideas which not only allow women to participate in what was previously considered activities or domains for only men, but, in my opinion, it's even more important that we value the work which women have always done to construct communities, families etc.]. (Female, 51-60, Spaniard and American, University Level Spanish lecturer)

\section{Extract 7}

Casi todos sus "refranes" hablan sobre violencia física. En la clase media de mi país la violencia hacia la mujer ya no es física, pero sigue existiendo [Almost all of these "proverbs" talk about physical violence. In the middle class of my country, violence against women is no longer physical, but it still exists]. (Female, 51-60, Mexican, Linguist)

\section{Extract 8}

Conocía muchos de los refranes, o variaciones de los que nos proponían, y creo que todos muestran un estereotipo social que sigue vigente en la sociedad. Además, he señalado que no siguen existiendo actividades 
propias de cada sexo, porque no creo que existan, pero eso no quiere decir que el resto de la sociedad no lo piense [I used to know many of the sayings, or variations of those proposed, and I think they all show a social stereotype that is still valid in society. In addition, I have indicated that there are no gender specific roles because I do not think they exist, but that does not mean that the rest of society is of the same opinion]. (Female, 1830, Spaniard, University Lecturer)

Thirdly, as mentioned above, the heightening of social awareness against gender discrimination appears to have curtailed the open manifestation of sexism. Indeed, in February 2014, the government speaker for the district town council of Jaén (Spain) made headlines in several Spanish newspapers (el diario, europapress, 20 minutos, and la gaceta de salamanca etc.). ${ }^{8}$ It was reported that he publicly used the proverb a la mujer y al papel, hasta el culo se ha de ver [women and papers need to be scrutinized thoroughly] while on official government duty for which reason he faced serious criticism and had to make a public apology. This confirms two things. In the first place, it demonstrates that some misogynous proverbs are still used. Secondly, judging by the barrage of criticisms which compelled the government speaker, as well as his other party members to apologise publicly, one can infer that the usage of androcentric proverbs produces public aversion and criticism. Linguistic androcentrism has therefore been curtailed by an awareness of the harmful effects of gender inequity. This has provoked a phase in which some misogynous proverbs are declining, while new and less distasteful ones are creatively metaphorised and popularly adopted e.g. esposa con blog no hace comida [a blogger wife does not cook]; la esposa con chat, el marido a Pizza Hut [the woman chatting on her phone, her husband at PizzaHut].

In addition to these factors, Martinez Garrido (2001) proposes other reasons for the apparent disappearance of androcentric proverbs.

A pesar de la pérdida de uso de muchos de nuestros refranes misóginos (sin embargo, no tan definitiva como en un principio podría pensarse), su vigencia continúa siendo un hecho real en el español y en el italiano hablado de zonas urbanas, al menos en contextos humorísticos, jocosos e irónicos, en los que el refrán misógino se utiliza indirectamente. En tales casos la misoginia, aunque camuflada, sigue estando presente desde la misma contextualización irónica y ridiculizadora con respecto a las mujeres en las que el refrán queda insertado [Despite the lack of usage of many of

\footnotetext{
${ }^{8}$ The news report is available at the following websites: http://www.20minutos.es/noticia/2057101/o/garcia-anguita/ pp/mujeres/; $\quad$ http://www.lagacetadesalamanca.es/nacional/2014/o2/13/portavoz-pp-jaen-mujer-papel-culover/111964.html; http://www.europapress.es/andalucia/noticia-psoe-critica-verborrea-machista-garcia-anguitadecir-mujer-papel-culo-ver-20140212164628.html; http://web.psoe.es/provinciadejaen/news/717020/page/psoejaen-deplora-las-lamentables-palabras-machistas-garcia-anguita-la-mujer-papel-hasta-culo-ha-ver.html
} 
Lomotey, B.A./Towards a sociolinguistic analysis of the current relevance of androcentric proverbs in Peninsular Spanish

our misogynistic proverbs (however, not as definitive as one might at first think), its validity continues to be a real fact in the Spanish and Italian spoken in urban areas, at least in humorous and ironic contexts, in which the misogynistic proverb is used indirectly. In such cases the misogyny, although camouflaged, continues to be present from the same ironic and ridiculing contextualization with respect to the women about whom the sayings are made]. (p. 84)

\section{Conclusion}

Some Spanish proverbs, like many others around the globe, project androcentric views. Results from the study confirmed that while certain categories of these proverbs appear to be phased out, some are still in use albeit to a minimal degree, and mostly, covertly. Although proverbs which reflect hostile sexism can still be found in literature that aims at collecting and analysing proverbs, they appear to have lost their popularity among speakers. On the other hand, proverbs that are reflections of covert and benevolent sexism seem to have maintained their well-established popularity. This demonstrates societal awareness and sensitivity towards the negative effects of gender bias and it confirms a significant success in feminist attempts to eliminate sexism.

Nonetheless, this study was an exploratory one that aimed at examining an aspect of proverbs that has not received much attention, i.e., their current relevance. The discussion of the results lays foundation for further empirical research investigating the current relevance of proverbs and their contribution to gender violence. It would be beneficial to repeat the study with a larger corpus and with different methods that would focus on language in use. 


\section{References}

Allport, G. W. (1954). The Nature of Prejudice.Reading, MA: AddisonWesley.

BOE. (2004). LEY ORGÁNICA 1/2004, de 28 de diciembre, de Medidas de Protección Integral contra la Violencia de Género. Boletín Oficial del Estado, 313, 29 diciembre 2004, 313, 42166- 42197.

Bosch, E., Victòria, F., \& Alzamora, A. (2006). El laberinto patriarcal: reflexiones teórico-prácticas sobre la violencia contra las mujeres. Barcelona: Anthropos.

Calero Fernández, M. Á. (1999). Sexismo Lingüístico: Análisis y Propuestas ante la Discriminación Sexual en el Lenguaje.: . Madrid: Narcea.

Crida Alvarez, C. A. (2001). La mujer en los refraneros espanol y griego: estudio sociocultural a traves de paremias contrastadas. Paremia, 109-110.

Davies, M. (2002). Corpus del Español. Retrieved July 26, 2017, from Corpus del Español: 100 million words, 1200s-1900s.: http://www. corpusdelespanol.org.

DonAabangens, R. (2010). Coleccion de Adagios o Refranes Espanoles (1861). United States: Kessinger publishing.

Fernández Poncela, A. M. (2012). Sexismo léxico-semántico y tensiones psíquicas “¿Por qué Dios creó a la mujer bella y tonta?”. Educar, 48, $175-196$. 
Lomotey, B.A./Towards a sociolinguistic analysis of the current relevance of androcentric proverbs in Peninsular Spanish

Instituto Cervantes. (2000). Lengua. Retrieved July 26, 2017, from Centro Virtual de Cervantes: http://cvc.cervantes.es/lengua/refranero/ficha. aspx?Par $=58885 \&$ Lng $=0$

Instituto de la Mujer y para la Igualdad de Oportunidades. (2019, February 12). Mujeres en Cifras - Violencia - Víctimas Mortales por Violencia de Género. Retrieved February 20 , 2019, from Instituto de la Mujer: http:// www.inmujer.gob.es/MujerCifras/Violencia/VictimasMortalesVG.htm

Lakoff, G., \& Johnson, M. (1980). Conceptual Metaphor in Everyday Language. The Journal of Philosophy, 77, 453-486.

Martínez Garrido, E. (2001). Palos, animales y mujeres. Expresiones misóginas, paremias y textos persuasivos. Cuadernos de Filología Italiana 8, 79-98.

Mestre Chust, J. V. (2007). La necesidad de la educación en derechos humanos .Barcelona: Editorial UOC.

Philips, S. U. (2003). The power of gender ideologies in discourse. In J. Holmes, \& M. Meyerhoff, The Handbook of Language and Gender (pp. 252-276). Oxford: Blackwell.

Swim, J., Aikin, K., Hall, W., \& Hunter, B. (1995). Sexism and racism: oldfashioned and modern prejudices. . Journal of Personality and Social Psychology, 68, 199-214. doi:10.1037/0022-3514.68.2.19

Taylor, A. (1996). The Study of Proverbs.Cambridge: Cambridge University Press.

Tirado Zarco, M. (1987 ). Refranes. Pedro Muñoz: Ediciones Perea. 